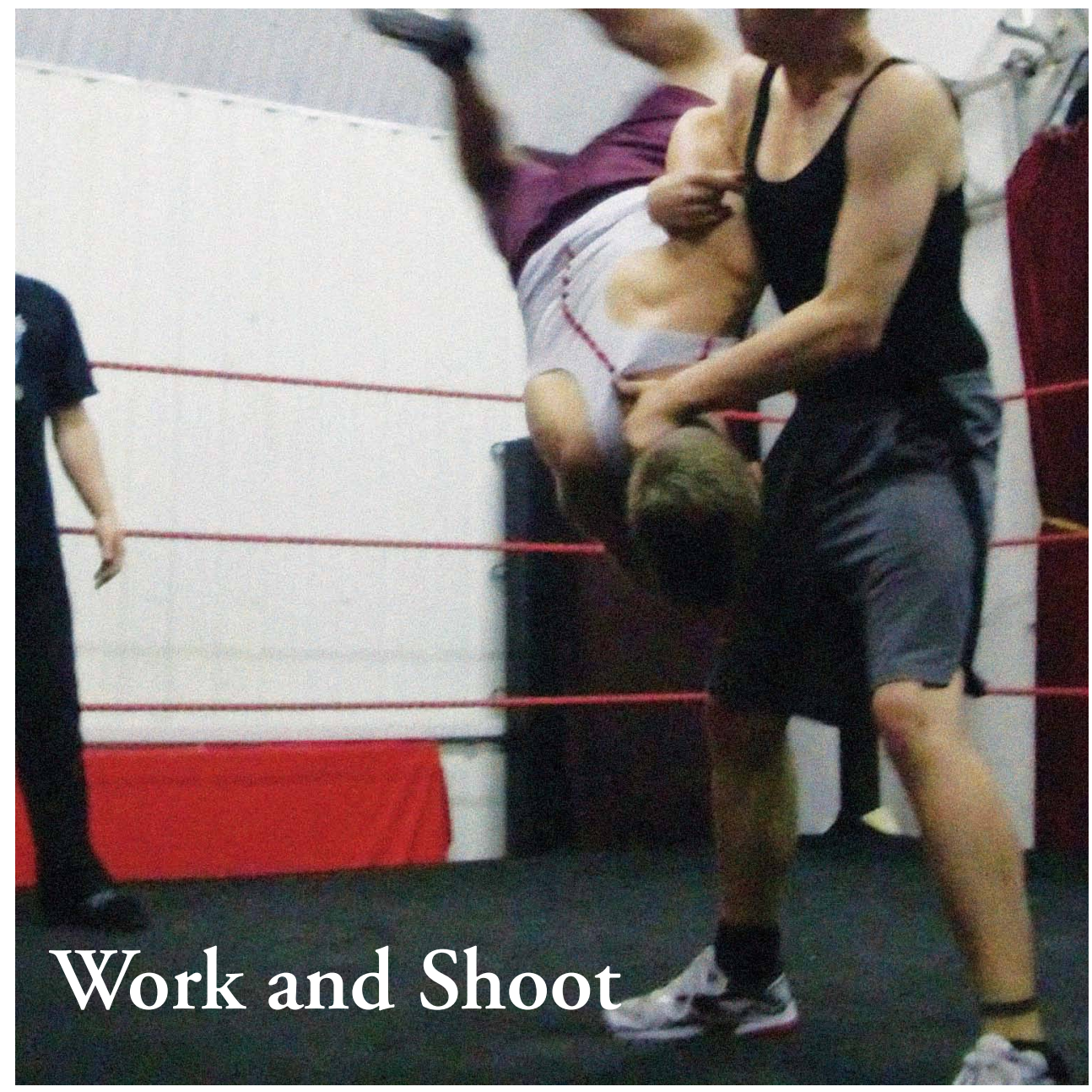

\title{
Professional Wrestling and Embodied Politics
}

\section{Broderick D.V. Chow}

I'd been "locking-up" for months before I learned how to do it properly. A lock-up is the starting point of countless professional wrestling matches. The left hand grasps the back of the partner/opponent's neck. The right grabs or drapes over the partner's bicep. The two wrestlers mirror each other in a hold that establishes - to the crowd, at least - who is stronger, who is dominant. Left foot forward, right foot behind, feet slightly wider than shoulder-width: establish a strong base. Circle the ring (always counter-clockwise), work "loose," don't forget to "sell." Watching two pro-wrestlers lock-up in the ring, muscular and intimidating bodies competing for dominance, the closest analogous image is of two stags rutting.

Broderick D.V. Chow is Lecturer in Theatre and Drama at Brunel University, London, UK, where he teaches theatre history and leads the musical theatre strand of the BA Theatre program. His research concerns the intersections of performance practices, politics, economy, and industrial change, especially in the world of work. He has also written on choreographic practices, parkour (free-running), the Olympics, and actor training. Broderick is currently preparing an autoethnographic project and monograph on the fitness industry, masculinity, and the neoliberalization of work. He is coeditor (with Alex Mangold) of Žižek and Performance (Palgrave, 2014). broderick.chow@brunel.ac.uk 
I circle the mats with my partner, locking-up with eyes before we lock-up with arms, and then, on some sensed, but nearly invisible signal, we charge into each other, bodies crashing, arms finding their way into the hold. Our bodies are there before we are. There is also something satisfying about "grappling," the feeling of strength tested against the strength of another. It reminds me of the way wrestling in ancient Greece was a pure form of physical "agon," or struggle. It is an ancient political principle embodied in the present. This was, initially, the way my body understood locking-up.

We are doing the usual drills on a Monday night. We pair off on the mats, and tonight, because there is an odd number of wrestlers, G.B., the head trainer, works with me. G.B. is six foot two, with a bodybuilder's physique and an enormous tattoo running up both arms and across his shoulders and upper back to cover both pectorals. In person and as a teacher, G.B. is kind and supportive, a sort of Essex "cheeky-chap." Yet physically, he is intimidating, and as we face off, I am wary. "Go!" he says, and we lock-up, in the way I know: left hand to back of the neck, right hand grabbing bicep, struggle for dominance. "Stop," he says, "loosen up. Again." We go again, and he stops again and admonishes me. "Listen, why're you blowing out everything on the lock-up? It ain't real, yeah? Light touch. Like this" (14 May 2012). ${ }^{1}$ Without moving, G.B. demonstrates the proper way to lock-up. The quality of touch surprises me with its lightness. "There, OK? Now you can respond to the other person," says G.B. With a true professional wrestler, there is no bearing down or test of strength. All the exertion and muscular strain turns out to be a "sell," a fake or con. The struggle is perceived not because it is "real," but because it is communicated to the audience. Not for the first time in my learning to wrestle, I realize that I have been "worked."

This story illustrates the embodied politics of this extraordinary theatre of the body. In August 2011, I began learning to wrestle at a small but growing professional wrestling school in Bethnal Green, East London. Coming from a background in physical theatre and dance, I was initially interested in the potential applications of professional wrestling to my artistic practice. ${ }^{2}$ What I found was a physical practice that was far more interesting than its status as a curious and often maligned popular entertainment. While seemingly violent and antagonistic, prowrestling is actually a practice of caring for the other. This is illustrated by the lock-up, a corporeal embodiment of "paraconsistent logic" (where a predicate and its negation are true at the same time). It is a hold that is not a hold, a struggle against the other that is at the same time cooperative. I began to read past wrestling's spectacular surface and became cognizant of issues connected to corporeality: its status as a form of shared theatrical labor that allows for participants to model and practice a political principle of friendship, regardless of difference. In doing so, wrestling opens the possibility for affiliations outside of accepted structures of kinship or political identity — communities of shared practice, rather than shared identity.

In professional wrestling, the word "work" is used in a number of ways, and this network of meanings hints at my political reading. "Worked" fights emerged in early-20th-century

\footnotetext{
1. All quotes, whether remembered or transcribed, unless otherwise indicated, are from my fieldwork at The School in East London, United Kingdom, from August 2011 to August 2012, as well as follow-up informal in-person and online conversations from December 2012 to May 2013. Quotes transcribed from notes are dated.
}

2. Indeed, throughout 2012, my collaborator, Tom Wells, and I created the dance-theatre performance Work Songs, drawing on a physical method based in contact improvisation and wrestling. The work has been presented in the United Kingdom and Germany, and is documented in my article "Time + Materials" (2013).

3. For a discussion of "paraconsistency," see Graham Priest's article on the subject in the Stanford Encyclopedia of Philosophy ([1996] 2013). The philosopher Slavoj Žižek also discusses "paraconsistency" in his latest work on Hegel (2012:1010).

Figure 1. (facing page) J., an experienced wrestler, demonstrates a body-slam on another trainee, at The School, Summer 2011. (Photo by Broderick D. V. Chow) 
American wrestling, as promoters discovered they were able to make more money by determining the outcome of matches (the "finishes") in advance. Today, wrestlers are not called "wrestlers," but "workers." One "works," that is, attacks, a specific body part. One "works" the crowd, "selling" the staged violence as real, a usage that reveals the origins of wrestling's argot in the confidence tricks of traveling carnivals, fairs, and medicine shows. Most significantly, "working" is a physical improvisation in which one worker responds to another's somatic, visual, and aural cues. "Work" in this sense, really means "working together." The counterpoint to the term is the word "shoot," another term derived from carnival language (i.e., "straight shooter"), meaning something that is real and not fixed. This often refers to moments of accidental or intentional but noncooperative violence; the moment when "kayfabe," the portrayal of staged events as genuine, is broken by a genuine event, and actual harm or injury may occur. ${ }^{4}$ The everpresent possibility of shoot, I would argue, makes wrestling exciting. The potential for real violence gives wrestling its unique frisson, but also makes working into an ethical practice.

Work implies a politics beyond what is actually represented in the ring. Within the squaredcircle, wrestling acknowledges and values labor. Not what Marx calls abstract labor (labor-power as variable capital that is secreted away in the exchange-values of commodities), but labor as the corporeal act of making and doing. Therefore, I theorize "work" in relation to wrestling as work, that is, the conditions of labor in wrestling.

After 20, maybe 30 repetitions of the lock-up - again, again, again — trying to get the correct light touch became as tiring as fully exerting myself. My forearms and shoulders burned. Speaking to another trainee later, I puzzled over why it was so important for G.B. to drill lockups in this way. She didn't know either, but suspected that it was because they were difficult to learn. Your tendency is to push, to "be stiff." "But working loose, working together," she said, "it's a way of allowing something to happen."

The methodology employed in this article is not, strictly speaking, ethnography. Sharon Mazer's ethnographic study of Johnny Rodz's wrestling gym in New York City published as "The Doggie Doggie World of Professional Wrestling" in TDR in 1990, and subsequently expanded into a monograph (Mazer 1998), has already done much of this groundwork, though it is lacking in one important area. In a 1997 article, Laurence De Garis, a former professional wrestler and ethnographic researcher who was one of Mazer's informants, criticizes Mazer's work for what he referred to as its "transcendental subject position" (De Garis 1997:66). Mazer, he argues, performs her privileged outsider position by her refusal to get in the ring herselfand thus misses crucial points about wrestling. De Garis proposes a "sensuous ethnography": "The point is that language and sight are limited in ways that tactile sensations are not" (71).

Following De Garis, corporeality and tactile sensations are the objects of my research. My body is both the tool of my research and its primary site of inquiry. If my research is ethnographic, it is not ethnographic in the sense of trying to depict an unfamiliar "world." I did not enter into wrestling as a naif, exploring a hidden community of secret knowledge and mysteries. I have a background in physical theatre, and my motivation to learn wrestling was similar to performance scholars who train in tango or trapeze: a genuine curiosity to explore the physical capacities of my body. Therefore, in this article I present my body's process of learning as the primary data of my research. I have represented names of wrestlers as initials and I give no background details, barring brief physical descriptions where required. The name of the wrestling school is represented as The School. It is important, for the understanding of the practice, to detail the words and voices of other more experienced trainees, but crucially, they are not "characters" in a literary sense, nor do I intend to "speak for" anyone else other than myself.

\footnotetext{
4. A worker may suddenly "shoot it out" with his partner as a result of ill feeling between them, or as in a tag-team match I watched at the Progress Wrestling promotion in Islington, London (June 2012), in which Velocity Viper Alex broke his tibia, "shoot" can simply be the result of a hastily tied boot.
} 
My subject-position is therefore similar to Barbara Browning's in her 1995 study of Brazilian samba, where she tells us that "fieldwork" was never her intention. Like Browning, the purpose of writing is to struggle with communicating something that is known through the body: "There are things I learned in Brazil with my body, and some of these things it has taken years to learn to articulate in writing. But that is not to say that they were without writing when I could only speak them through dance" (Browning 1995:xi).

For me, the focus is always the body. By looking at the way wrestlers build and train their bodies, we can understand not only how processes and forces of wage labor and capital shape, discipline, and injure their bodies, but also how physical practices can be forms of resistance. As Michel Foucault tells us, the disciplined body is also a site of resistance.

\section{Work}

\section{The Ethics of Fake Fighting}

\section{Learning to Fall}

On my first day of training, it felt appropriate to discover that The School was actually a small performance space and alternative art gallery, tucked under a railway arch in East London. After all, professional wrestling and theatre cross paths throughout both their histories. Spectacle is wrestling's substance and its meaning. Like boxing, European wrestling in modern times was originally presented in circuses, fairgrounds, and theatres. Part of the pleasure for audiences was admiring the developed bodies and feats of strength of athletes such as Georg(e) Hackenschmidt, an Estonian strongman who wrestled under the name the "Russian Lion" (Rickard 1999:130). For the spectators of the Lancashire style "catch-as-catch-can" or Irish "collar-and-elbow" wrestling in late-19th-century America, gambling on the outcome of a match was less important than a good show (Beekman 2006).

Learning to create this spectacle is a three-day-a-week business. G.B., the head trainer and a fairly well-known "heel" (bad guy) in British wrestling, runs The School with G.V., another professional wrestler, and classes take place as ongoing drop-in meetings: Monday evenings for beginners, Tuesdays intermediate, Wednesdays for pros and those on the verge of their first bookings. Class sizes on these evenings vary from 10-12 to 25-30, and the trainers also run "privates," training sessions with very small groups of 4-6. The ring is erected one week per month, the same week the gallery presents its extremely popular wrestling show, but otherwise training takes place on two-inch-thick foam mattresses. The trainees are diverse, including aspiring and working pro-wrestlers, actors, dancers, performance artists, and people simply looking to get fit. The split of men and women is around 60/40. A high proportion (around 30 percent) of trainee wrestlers appear to be people of color. Many identify as British, but there are many others from other nationalities within the EU or abroad. Some identify as gay, lesbian, or queer, and others seem hegemonically "straight." Body types vary enormously, from the muscular physiques common in WWE wrestlers, to the very overweight or very thin. The median age seems to be around 25-35, although there are wrestlers over 50 and one or two teenagers (The School is an 18-plus environment).

We start with conditioning, a challenging combination of cardiovascular exercise, stretching, isometric and bodyweight strength training, and core training. Conditioning the body is essential to pro-wrestling, not merely to acquire a certain body shape, but for "not feeling like you're gonna die every time you carry someone," as another trainee remarked. After an hour of pushups, crunches, planks, and some freestyle dancing to house music, the small gallery is as warm as a sauna and we are dripping with sweat. After conditioning, the trainers drill students in "bumps" (how to fall safely, similar to break-falls in martial arts such as Judo), rolls, "chain-wrestling" (improvising moves with a partner), and more spectacular moves including "high-flying" (moves that require leaps, often from the top rope of the ring, including "moon-saults" and "splashes"), throws ("suplex," "power-bomb," "hurricanrana"), and pins. 
G.V. calls wrestlers "stuntmen for the theatre." But unlike stuntwork or staged combat, wrestling is largely improvised, with workers coming up with a loose structure and "finish" and working together to improvise around this. Wrestling therefore emphasizes kinaesthetic and proprioceptive awareness - the perception of the body's positioning in relation to itself and other bodies. The trainers do not use these terms, but instead speak of "ring awareness," "timing," and "biomechanics" (though their usage of this term, I believe, does not consciously refer to Vsevelod Meyerhold). G.B. illustrates kinaesthetic awareness with an analogy to music. "You're like a conductor-you're conducting a line of energy from one side of the ring to the other," he says, and then, grabbing the forearm of an experienced trainee, swings him across the canvas (this move is called an Irish Whip). The trainee's back crashes into the padded corner post. "You feel that, right? You feel that 'ping'?" "Yeah." "See — that's timing! You can feel it!" (1 November 2011).

Anyone who prefers specific instructions in their lesson might bridle at the vague terms and unnecessary mystification in the previous example ("energy," "that 'ping,", "you feel that, right?"). But this vagueness actually points to an important aspect of wrestling as a practice - it is a form of tacit physical knowledge.

One Tuesday evening it seemed G.B. had turned into a brutal ballet teacher. "Again!" he shouted, "again!" Positioned in the four corners of the mat, without count or signal, myself and three other trainees began to shoulder roll from one corner to the other, avoiding, or trying to avoid, colliding with each other. Over and over, either I, or another trainee, would fumble or mis-time one of the rolls, we would hear the shout, "Again!" and we would silently retreat to our original positions with the weariness of a veteran ballerina taking her place at the barre. By the time G.B. freed us to begin working with the next four trainees, my shoulders were bruised and tender from repeated contact with the floor. The repetition of what in fact seems like a fairly incidental part of a wrestling match reveals its importance:

Why do you think I made you do them rolls so many times? In the heat of the match there isn't no time to think, you just gotta get out of the way so that the other bloke's dropkick don't actually hit you! Ring awareness, yeah? Timing. It's like...you have to see everything that's going on even if you can't see it. [Recounting a match from a weekend show he had wrestled in] You remember the tag-team Sunday? Who was there? [Some bands go up] See, you can't be thinking when you're in there, if P. is coming at you with a rana [hurricanrana] and there's three other guys in there, and you have to jump over him, and then he's coming at you and blowing powder and glitter in your face [...] You can't be worrying about your roll going the wrong place. It's gotta become part of you. (8 November 2011)

What is physically counterintuitive and difficult becomes internalized and embodied; knowledge made flesh.

My own struggle was with "falling," as captured in a journal entry written hastily on the Underground journey back to my home in Camden:

The thing I find myself needing to overcome is fear and lack of confidence. It means my moves are all disarticulated. My back bumps [a backwards fall onto the mat, in which the lower trapezius and rear deltoids connect with the floor] are especially bad. G.V. says I'm "Transformering" it - I guess he means I'm breaking apart what should be a single fluid motion into constituent parts. I understand that intellectually, but (a) that's how I learn stuff, by breaking it down, and (b) it's still really difficult to overcome the fact that it's unnatural to fall backwards. (9 July 2012)

"Bumps" are in some ways the most challenging technique to teach in wrestling. While other moves can be passed on through shared touch, when you fall, you fall solo. Proper technique is taught through demonstration, imitation, and correction. In the case of a back bump, the blind 
backwards fall so challenged my everyday modes of vertical orientation that even months into my training I was still cheating the move, using my hands to break my fall first, even though this risked injury to my wrists and fingers. "You bump really dangerously," said G.B., sternly.

Later in the month, G.V. drilled us on back bumps in a different way: on his clap we would fall backwards and bump safely. Having to respond on cue, without "thinking," I discovered that despite my earlier frustrations with a body that refused to cooperate with what I mentally understood, my body already knew far more than I did. The experience was akin to learning to ride a bike. One minute I couldn't, and the next I could.

\section{Working and Working Together}

The wrestling promoter decides in advance who will win ("go over" or "get over") based on audience response to certain workers or a planned storyline that might stretch over several events. The promoter, however, is not a director in the theatrical sense so the workers themselves devise the internal structure of the match. Workers structure matches according to the basic logic of good and evil ("face" and "heel"), ${ }^{5}$ incorporating moves and pins they enjoy and that will best showcase their abilities. Still, matches are mainly improvised, with "chain wrestling," that is, stringing together a set of moves, often derived from legitimate grappling sports, being the primary and most important improvisational technique.

Because the outcome, or "finish," of a match is already determined in advance, it seems unnecessary to improvise them at all; choreographing (and rehearsing) the match to avoid any potential for injury might seem more logical. Some workers at The School maintain that not scripting a thorough choreography backed by rehearsal was due to a lack of time:

I remember when me and C. were doing two shows a night on the weekends we'd drive all the way from London to Birmingham, and be working out the match in the car, "Okay, you do a clothesline there," ... and of course we'd be late and pulling on our boots in the car and running in just in time before you were announced. (21 May 2012)

However, many workers also take pride in being able to improvise and work under pressure in this way. One told me: "the more you plan your match, the more likely you are to just run through it. If it's not written, then the reaction is legit...and...real, in a way" (9 May 2013). Similarly, De Garis notes that many older workers despair of the increasingly choreographed nature of wrestling matches for television, in which dress rehearsals are sometimes conducted before broadcast (De Garis 2005:207).

Learning to chain is about more than executing the move "correctly," it is about developing kinaesthetic empathy. The majority of moves employed in chain wrestling are "legitimate" moves from Greco-Roman or Freestyle wrestling, adapted to ensure they can be performed safely and repeatedly. For example, in a "wrist-lock" one wrestler grasps his partner's hand, twisting the arm in such a way that the wrist is bent at a painful angle. This move can, if applied with enough force, as in a street fight, disarm an attacker. In pro-wrestling, the defending wrestler keeps his elbow bent, in order to prevent injury. The attacking wrestler maintains what the trainers refer to as a "Playstation" grip, which mimics the shape, as well as the light touch, of two hands manipulating a video-game controller. A wrist-lock can be transitioned into a "hammer-lock" in which the defending partner's arm is bent behind his back. The attacker must maintain a light grip on the partner's hand; but with the hand hidden behind the back, and maintaining close bodily proximity, the workers are able to "sell" the move, communicating pain to the audience through faces and flexed musculature. The only site where pressure/tension is not exerted in such a move is the hand itself.

5. Other scholars have elaborated upon the narrative structures of matches in great detail. As my work concerns instead what happens between bodies, I refer the reader to De Garis (2005), Campbell (1996), Jenkins (2005) for further information on "heel heat" and so on. 


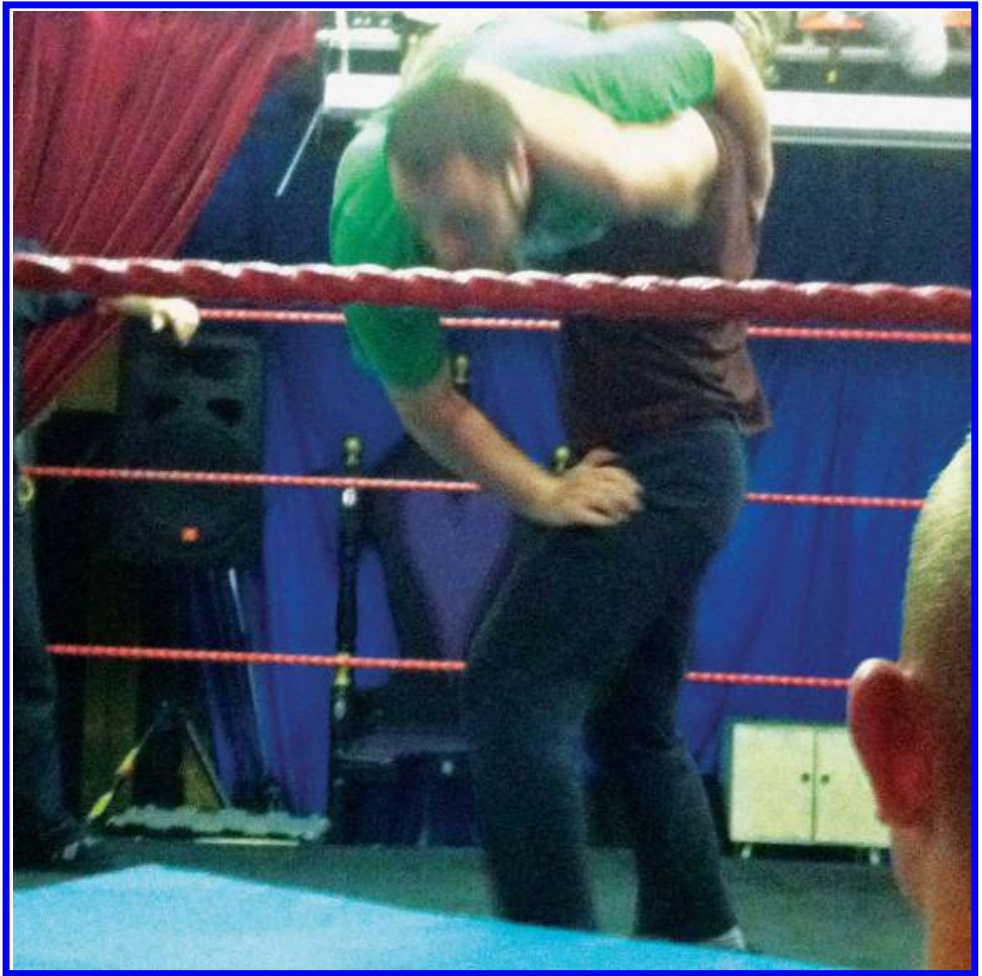

Figure 2. S., a newbie, is lifted into a scoop slam by another trainee, The School, Fall 2011. The worker being "thrown" assists the worker doing the "throwing" by placing his hand or arm on the slammer's thigh, revealing the collaboration even in an aggressive move. (Photo by Broderick D.V. Chow)
In each training session, after learning a number of moves, we gather on the perimeter of the mats (or the apron of the ring) to improvise and incorporate these moves in a format similar to a contact improvisation "jam." Two trainees go into the center of the ring and wrestle until one tags another trainee, who then takes his or her place. For many trainees at The School, myself included, these jams are the most enjoyable part of training. There's a loss of self-consciousness and a feeling of absorption in working with another person. On one occasion, T., a trainee of about two months, was working with R., who had much more experience. As their chaining progressed, T. was flipped upside down and hoisted onto R.'s shoulders, who then slammed him down onto the mats safely and in complete control. "I didn't know what was happening!" T. remarked. "I just like, let it happen. Yeah, but it was good! [To R.] Nice one, mate" (17 January 2012). This kind of single-mindedness recalls Mihaly Csikszentmihalyi's concept of "flow" (1975), a state of deep mindfulness and focus that he observed in jazz musicians, children at play, and skiers, among others. Flow is complete absorption in a task and the ideal state of unalienated work, as Lars Svendsen summarizes: "When we are fully immersed in work we lose our sense of having a distinct self and rather become one with the activity" (2008:44). Applying this concept to wrestling work we might say that it is a process of being in flow, becoming absorbed collaboratively and completely with another person.

My own moment of absorption came when we were told to go and prepare a match with a partner and present it in the ring. I was paired with J., who had been wrestling for a year or so and was starting to be booked by other promotions.

J: Okay, so why don't we start with headlock, then take-down, I'll get you in head scissors, you bust out, we lock-up, then chain for a bit...I dunno, then front face-lock, fight out, we do that spot that G.B. showed us, then finish... What do you know how to do?

B: I can do some pins...

J: Magistral? [I nod] OK. (28 May 2012) ${ }^{6}$

6. A magistral is a graceful looking pin in which one worker forward rolls under the other. 
The level of improvisation required was substantial. While we started off well, after chaining for a few minutes I could not remember what came next. Grabbing me in a front face-lock (the opposite of how it had been planned) he whispered in my ear: "Fight out." The cue was enough for me to overcome my self-consciousness, to forget everything and continue. We got to the finish, the magistral. The other trainees hollered in approval, and I felt a flush of excitement and pride: my first "pop."

\section{Working Loose}

Another in-training match a few weeks later went far less well. My partner and I felt in genuine competition with each other. We had been told to pick a gimmick and play a match as either a heel or face (good guy). The extra level of having to sell a dramatic storyline made me forget my training. I genuinely started to struggle against D. As G.B. tried to dissect the match ("What went wrong? Loads of things."), D. told the rest of the trainees: "He was going all over the place, and really stiff. It felt really panicky and dangerous." G.B. says: "You gotta slow down, learn to work loose. [...] Don't worry about it, you're learning" (18 June 2012). My face burned.

Working "loose" distinguishes pro-wrestling praxis from other legitimate forms of combat sports such as amateur wrestling and MMA. Both trainers constantly stressed the importance of working loose, yelling from the sides: "loosen up!" The verbal explanations of certain holds emphasized a loose grip and malleable body, sometimes resorting to hilariously vulgar metaphors. As G.V. said at one of my first training sessions in August 2011: "After you get the guy in wrist-lock, and you wanna twist his arm, you make a circle with your fingers. Keep them loose. You barely want to touch the guy's arm. I call this grip 'Slack Anal."” The image and feeling of the opening made between one's two hands as a loose sphincter was undeniably helpful.

Working loose also takes a long time to perfect, because it is counterintuitive to the violence that is being displayed. Mazer notes that a wrestler must "contain his propensity for actual violence and [...] restrain his desire for dominance in order to make his performance of violence accessible to and engaging for the audience" (1998:10). In his study of American independent wrestling, R. Tyson Smith notes that pro-wrestling praxis is "antithetical to the ordinarily hard body of the athlete" (2008:162). A., a female trainee, told me after my failed match, "It takes a long time to learn. I found out recently that all the guys used to say don't get paired up with her, because she's gonna be stiff."

Smith draws attention to the two contrasting sets of emotions workers must generate. Outwardly, they must generate "frontstage" emotions to "evoke passionate feelings among audience members through acts of injustice (or justice)" (162). Inwardly, or between each other, they must feel mutual empathy and trust. While Smith's analysis over-simplifies the nature of audience response, ${ }^{8}$ his observations on work between wrestlers points to the ethical nature of wrestling praxis. First and foremost, he highlights that wrestling requires trust, providing a rather moving sketch from a grassroots wrestling show in the United States. Recounting a "finishing move" performed from a 10-foot metal ladder, one wrestler says: "He said, 'Do you have me?' and I told him I had him. I said, 'No, it's alright...put your arm here.'” These exchanges, Smith points out, take place in quiet whispers as the crowd roars, "Kill him! Kill him!" Smith recalls: "The two performers then flew into the air and did a flip while embracing" (168).

Wrestling work, therefore, can be thought of as a practice of trust and care. In the ring, wrestlers put their bodies at great risk and trust that their partners will have the embodied knowledge to protect them. Being a safe worker does not mean one worker paternalistically

\footnotetext{
7. A "pop" is a spontaneous audience reaction, though as A. told me, referring to a rather spectacular move in her first match: "You feel like a little superhero — you get a little pop inside yourself too."

8. Smith's argument that wrestlers strive to evoke fear and anger comes across as too straightforwardly Aristotelian. In contrast, Mazer's 2005 analysis of audience kayfabe presents a more complex reading.
} 
protects or shields the other; rather, it is a process of mutually becoming vulnerable. During one intermediate class in late May 2012, we practiced "shoulder-checks," a move in which both wrestlers set off running, crash into each other, and back bump onto the mat. Executing the maneuver safely requires you to, at the very last second before impact, raise your left arm across your chest so that the large, muscular part of the upper forearm and the front deltoid make contact with your partner. I was paired with M., an up-and-coming worker. At five foot four, M. is shorter than me, but twice as wide, and covered in tattoos and piercings. In his publicity materials he wears a leather dog collar and is compared to a pit bull. Were I to encounter him on the street, I would probably not shoulder-check him. M. noticed that I had a tendency to turn my body too much, "as if [I was] trying to protect myself" — of concern to him because attempting to protect oneself makes the move more dangerous. To lay oneself open to danger makes the move more safe - but it also requires a great deal of trust, as one is placing one's safety in the hands of another. This other, of course, might be a stranger. The ethics of pro-wrestling are an ethics of openness.

This account of training demonstrates that wrestling praxis builds a contradictory body. The conditioning required by training sessions (supplemented by additional training to develop a certain body type) along with the repetition of moves would suggest that workers develop what Michel Foucault ([1975] 1991) calls "docile" bodies, bodies adapted through discipline for participation within modern institutions. At the same time, the improvisatory nature of the practice and its demands for safety and care of the other suggest an alternative system of values and affinities. The powerful, hypertrophic body of the wrestler is put to the service of pliability and softness; wrestlers embody friendship while communicating antagonism and aggression.

\section{Shoot}

\section{The Political Economy of Professional Wrestling}

\section{Discipline and Precarity}

In his history of professional wrestling, Scott Beekman notes that the transition from wrestling as sport to pro-wrestling as theatrical spectacle began in a moment of direct capitalist exploitation: "[After World War I] promoters recognized that predetermined finishes kept fans interested in their product and left wrestlers at their mercy" (2006:ix-x). In a dialectical reversal, however, the removal of workers' autonomy to determine conditions of work and labor also produces its own resistance, by inventing a practice that generates collective agency.

Today more than ever, wrestlers labor under conditions that place enormous demands on their bodies without adequate remuneration, insurance, or job security. Jasmin Mujanović (2011) points out that in the United States "since 1985, well over a hundred professional wrestlers have died before the age of 65 ," a statistic that includes head injury, suicide, heart failure, and drug abuse (narcotics, painkillers, and anabolic steroids). Injuries are common, and there is no safety net for injured wrestlers except for individually purchased insurance packages. Wrestlers have no labor contract from promoters, often receive poor remuneration, and may be required to travel long distances between shows. Smith writes, concerning the US independent wrestling scene: "If there is compensation for performing, it depends on the given promoter and the size of the house attendance. Some promotions pay a small stipend for that night's performers $(\$ 25-\$ 75)$ but it is very common to receive no pay at all” (2008:160). There is also little opportunity for collective action, even in the highest tiers. For example, the WWE as a corporation "has gone to significant lengths to break up any potential emergence of a union for professional wrestlers" (Mujanović 2011). Legally, because workers are hired as "independent contractors," they cannot unionize, though there have been some efforts in Britain to encourage workers to join Equity, the actor's union (Frontier Wrestling Alliance 2011).

The labor economy of wrestling can therefore be described as "precarious." In a 2012 issue of TDR on "Precarity and Performance" (2012), Nicholas Ridout and Rebecca Schneider evocatively write: "Precarity is life lived in relation to a future that cannot be propped securely upon 
the past" (2012:5). More concretely, as a condition of labor, precarity refers to flexible and temporary employment. What Guy Standing calls "The Precariat" (2011) includes those workers who do not and cannot claim forms of security enjoyed under Fordist capitalism such as job security, pensions, stable working hours or contracts, and maternity pay. Under neoliberal economic policy, precarity has become an increasingly universal condition, affecting service-sector workers, temporary migrant workers, and salaried workers in the creative industries and other forms of "immaterial labor" (those forms of labor that produce information, affects, and attitudes, as opposed to material commodities; see Hardt and Negri [2000]).

But unlike the precarious nature of a shift-worker in the service industry, wrestlers are driven by a desire to "make it in the business." Like acting and other forms of performance, wrestling can be seen as a "passion industry," a term used by Sophie Hope and Louise Owen (2013) to describe the cultural and creative industries, where, like those striving to make it in professional sports, workers are driven by their passion for artistic and creative practice and will therefore endure difficult and unpredictable working conditions. The wrestler/worker prefigures and models the way in which precarious and unstable work forces workers in all industries to adopt certain disciplinary procedures in order to survive in a freelance world. Workers survive through repeat bookings, generally based on popularity and audience response. If a wrestler is popular, he or she will be determined in advance as victorious, as "getting over" in wrestling lingo. While what happens in the ring is not a true contest, wrestling is intensely competitive, as workers compete with each other for bookings, aiming at the Holy Grail: an audition for the WWE. How to "get over" was repeatedly emphasized at The School. Both trainers noted that one's "gimmick" (character and costume) was the most important aspect of wrestling, as "that's what makes you money." Discussing competition within the business, another wrestler noted, "[A] good wrestler is not just the skills, it's selling...you can be really skilled, but if you don't know how to present yourself, if you don't keep that link with your audience online, with putting your promo online, if you don't do all that then it's a bit wasted" (9 May 2013). But probably the most emphasized part of selling yourself is the body. Not what it can $d o$, but what it looks like.

According to Marxist theorist David Harvey, the body of the worker makes visible the worker's insertion into the circulation of variable capital-labor power as commodity (Harvey 2000:103). In wrestling, the visible marks that reveal the commodity status of the laboring body of the worker include scars, bruises, broken bones, dislocations, and excessive muscle gain. As evidenced by my observations of the training situation, informal conversations with experienced wrestlers, and testimonials by pro-wrestlers in Britain and North America (see Garfield 1996, Kluck 2009), workers often adopt a narrative of "no pain, no gain," in which the working subject (over)identifies with the physical labor of the performance, pushing past individual physical limitations. ${ }^{9}$ Wrestlers may work injured (Kluck 2009:33), or take part in "extreme wrestling" or "death matches" (which involve blood-letting with any combination of smashed fluorescent light tubes, barbed wire, ladders, razors, or staple guns, among other creative routes to selfinjury). But most common of all is the commitment to physical training and muscular development (what G.V. simply calls "working on your body"). Excessive weight training produces the hard surface of the body that is paradoxically meant to work in a soft and gentle way.

In the economy of wrestling, bodies of wrestlers are reproduced and endlessly circulated as commodities, their stripped, exposed, shaved, tanned, and hypermuscular images sold as posters, as action figures, in video games, and on other branded merchandise. A hypermuscular ideal is not secondary but central to wrestling as a spectacle. In their study of WWE match commentary, Danielle Soulliere and James Blair (2006) find that commentators repeatedly point out and

\footnotetext{
9. Of course, wrestling is not unique in its demands on the body — other forms of performance such as ballet or extreme forms of performance art put similar strain on the body.
} 
compare the muscularity of male wrestlers, praising certain wrestlers with adjectives such as "cut," "ripped," and "pumped."

One evening, upon returning home from training, I opened my laptop to find a posting by G.V. on the private Facebook group of the wrestling school that read, bluntly: "Everyone needs to work on their bodies a bit more now! Gym! Gym! Gym! Great skills \& Great Look [sic] is the difference between bookings \& sidelines!" On my return to training after a month's absence, G.V. commented to G.B.: "His body looks good. His triceps are massive! [To me] You been gymming? Good! You look good! Keep at it!" As Wacquant (2004) would say, as a result of my increased efforts in weight training and bodybuilding in the previous month, I increased my "bodily capital," though in a crude and literal way. The more mass I gained, the greater my capital. It is this simplistic 1:1 relationship between mass and value that one might argue is at the heart of the anabolic steroid abuse in the industry, which is thought to have lead to the tragic murder-suicide of Chris Benoit and his family (see Ronson 2007). I must emphasize that at no point during my training did I observe anabolic steroids or other illicit supplements being advocated or even discussed, though there was much discussion among trainees (myself included) of the best brands of protein powders and creatine.

Discussing the importance of "look" with other trainees I found an interesting ambivalence and acceptance of the pressure to maintain a certain bodily ideal. Some wrestlers were perhaps somewhat critical of the pressure the trainers put on certain trainees, but others accepted it as a part of wrestling life: "You're supposed to look like you're strong and everything, and if you look like anyone who could've just put on pants [underwear] and come in the ring, then it doesn't work." Or: "If [the WWE] has a choice between a guy that has awesome muscles, tall, tanned, and a guy who looks like either a bit too skinny, or has a bit of a belly, the choice is quickly made... Basically, the body shows the commitment" (5 December 2012; 9 May 2013).

\section{Power and resistance through friendship}

The designation of wrestlers as "workers" should by now seem apt. Wrestlers are paradigmatic examples of the wage-laborer who sells his or her "form-giving fire" (Marx 1857) to the capitalist (promoter). The precarious nature of this labor economy in which steady employment is almost unheard of, leads to the adoption of disciplinary procedures of the body. Wrestlers work with their bodies, they work their bodies, and their bodies show the work.

Foucault says: "power, after investing itself in a body, finds itself exposed to a counterattack in that same body" (1988:56). The counter-attack in this case is not solo, but a resistance between bodies. Within the structures of the buyer's market of labor, the actual praxis of wrestling I have described is where the labor of wrestling resists its own exploitation by producing alternative values that are difficult to commodify: affects, affinities, relationships. Knowing how to "work" (a form of tacit embodied knowledge) is an alternative form of capital that is circulated solely among wrestlers, and hence evades capture by promoters or the larger industry. It can be seen as akin to the pre-Taylorist organization of industrial labor, in which the craftsman, and not, as Harry Braverman points out, the manager or engineer, was the "chief repository of scientific production technique" ([1974] 1998:131). Counteracting a labor economy of individual free-agents, wrestling is a guild-like structure.

Guilds are essentially communities of shared practice. In one sense, they are closed to outsiders, but in another, by becoming competent in the practice, one can be admitted. This sort of affiliation through practice, rather than through shared identity, models a type of political relationship I want to conceptualize here as friendship. Friendship in this sense does not mean a social relation marked by feelings of warmth or happiness, though such feelings may be present. Rather it refers to, as postcolonial theorist Leela Gandhi writes, "all those invisible affective gestures that refuse alignment along the secure axes of filiation to seek expression outside, if not against, possessive communities of belonging" (2006:9). A politics of friendship, in other words, is a kind of radically open hospitality, which Jacques Derrida (Gandhi's major theoretical refer- 
ence) defined in evocative terms: "Let us say yes to who or what turns up, before any determination, before any anticipation, before any identification" (2000:77). While one might wonder how any practice requiring such a high level of physical ability can be inclusive, I am reminded that the trainers frequently described wrestling as a kind of "language," an embodied shibboleth: "A wrestler from Japan will be able to wrestle a guy from Mexico, even if they don't speak the same language and've never touched each other before" (G.V., 25 August 2011). Induction into the world of (wrestling) work erases differences of nationality and ethnicity.

This reading of the praxis of wrestling sheds new light on one of the problems of the genre: its use of racist, xenophobic, sexist, and homophobic stereotypes. Because wrestling requires extreme care and cooperation, it provides the means for a physical exchange to take place outside of identity and spoken language. In the early 1940s, an Argentinian wrestler of Italian descent, Antonino Rocca, was brought to New York City by a wrestling promoter and quickly rose to prominence. A tall, handsome wrestler, promoters gave him a stereotypically "macho" Italian gimmick, shamelessly playing up his ethnic heritage in order to draw in the local immigrant community. Yet the practice of physical cooperation and trust taking place between Rocca and his US opponent/partners - solidarity between immigrant and US citizen - might not have taken place were friendship based solely on identity. One might therefore read the history of wrestling not as a compendium of the most offensive stereotypes (see Maguire and Wozniak 1987), but rather as a place where the marginal, the excluded, and the immigrant have found friendship with others though a shared practice. The diversity of the wrestling school I attended bears this out. Therefore, the atmosphere of bravado, colored by casually racist jokes, sexism, and "Grapple Gay" taunts that in any other situation would be read as offensive, is complicated by another corporeal level of intimacy, safety, and care for the other's body.

Wrestlers as laborers (like actors, dancers, musicians, and performance artists) prefigure the ideal worker under post-Fordism, but their practice models possibilities for resistance. Precarity basically defines all workers as "free agents," promoting individual self-interest and fulfillment. Responsibility for survival is conceived of as individual (and competitive) rather than collective. Yet wrestling work, because of its highly physical and potentially dangerous nature, is cooperative to an unusual degree. Work, as I have experienced it, is about trust: laying down one's health and safety for another. In opening myself up to another I also protect myself. In this sense, friendship leads to solidarity.

\section{“Tapping out..."}

\section{Conclusions}

Wrestling practices the political principle of friendship, and opens up the potential for communities based on shared practices, rather than identities. It is important that this relationship happens through the body, rather than through verbal exchanges; while one might understand solidarity as a principle, a wrestler knows what it feels like. Raymond Williams distinguishes between structures as institutional or organizational, and structures of lived experience, what he calls "structures of feeling" (1977:127-35). My focus is on wrestling's structure of feeling.

This research raises some crucial questions to be addressed in further work. Firstly, any reading of wrestling work as inclusive is problematized by the representation of women wrestlers. As Mazer writes: "The performance of female wrestlers - even or perhaps especially when it is most like the performance of male wrestlers - invariably generates its heat as much from its implied (if not actualized) erotics as from its athletics and from its legitimizing effect on men's wrestling" (1998:118). In large television promotions, female wrestlers are explicitly gendered as such, and their gimmicks often pander to the most egregious sexist stereotypes ("blond bimbo," "gold digger"). Some might argue that male bodies are equally exposed in wrestling, with Paul "Triple H" Levesque providing the "beefcake" to Chyna's "cheesecake," as it were. However, the overall marginality of women's wrestling - it is uncommon to see more than one very 


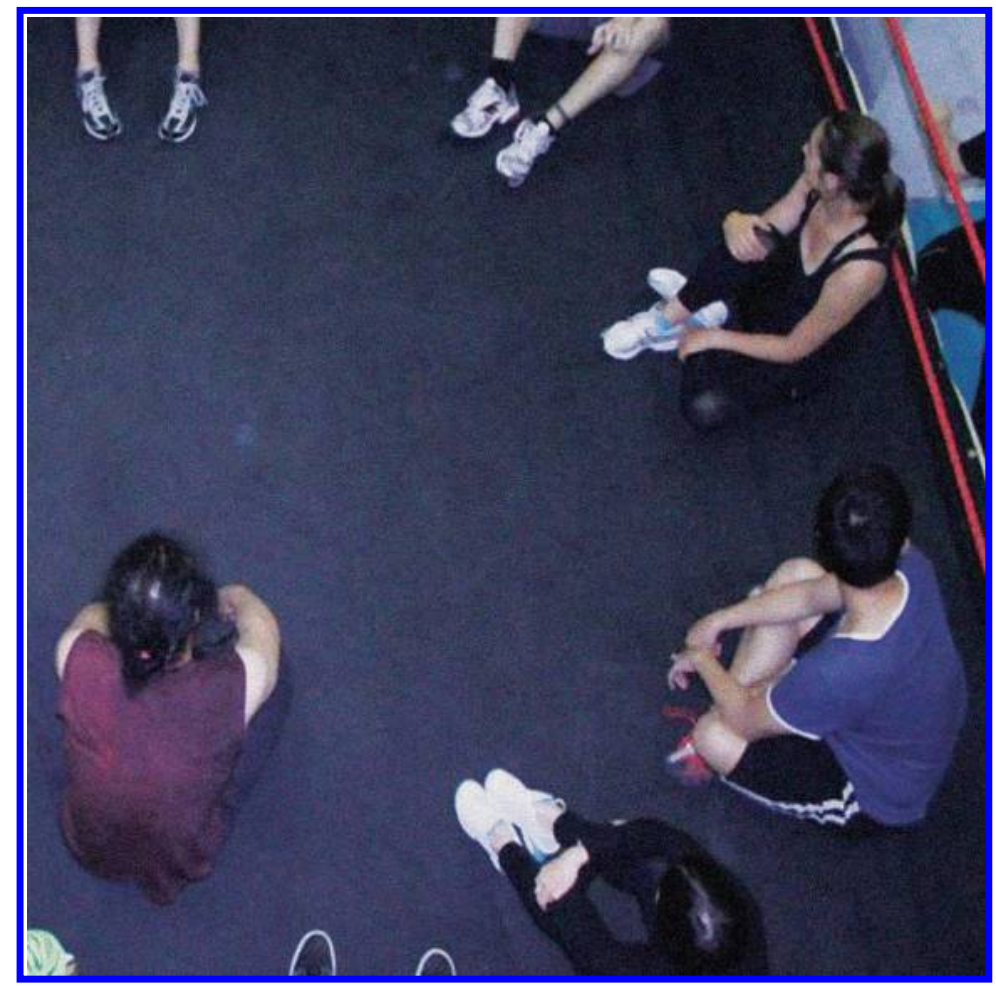

Figure 3. Trainees in the ring, Summer 2011. (Photo by Broderick D. V. Chow) short "divas" match on a WWE card-demonstrates that, at the level of the big promotions, there is vast gender inequality. While women made up around 40 percent of the trainees at The School, further research on the experience of women wrestlers must be done to determine if wrestling work as a form of embodied politics as I have analyzed it here, is mostly a "boy's club."

Secondly, as a model for resistance, wrestling work as a practice of solidarity largely relies on capitulation to authority; it does not transform its conditions but rather adapts to them. In essence, I have described the internal contradiction of wrestling's economic system, that relations characterized by exploitation and precar-

ity might instead produce friendship and solidarity. But the question arises of the ultimate value of wrestling work as a model for other forms of political action. I have addressed what work $i$; subsequent research might address what work can $d o$.

\section{Postscript: Troublesome Amateurs}

After each training session, I would write up my field notes on the long train journey — reflecting on what my body had learned and making attempts at theorizing the practice. I would discuss my thoughts with other trainees, who would help me in constructing a general picture of wrestling, and the wrestling scene. After completing an early draft of this article, I spoke at length with a few of the trainees about my conceptualization of wrestling work as resistance within the context of wrestling's labor economy. These conversations threw in some interesting complications.

Mostly, the other trainees were hesitant about agreeing with my reading, which one described as too "romantic." A., for instance, told me that the competitive nature of British wrestling was far worse than I had represented; with gossip about underhanded techniques in getting booked abounding (wrestling for free and undercutting other workers; being a "ring rat," that is, a female wrestler thought to give sexual favors to a promoter). "Does this take away the value in working together with a partner?" I asked. "Well...no. That's still my favorite part...and it's something that [fans] don't see, as much as they realize it's all faked. This is really working together with the body, but [fans] don't realize the involvement" (9 May 2013). Regardless of my conceptualization, it seems work as an alternative mode of value is generally appreciated. And certainly there was appreciation of the boundary-breaking nature of working with others: "There's all this bravado, no one's arrogant, you sweat together, you make mistakes, you get to know people in a different way."

Others noted that many promoters did care about wrestlers' knowledge of work, and that in a sense, work could not exclusively be set against the competitive nature of getting booked. G.B. told me: "You get these guys, they don't know how to work, how to tell a story - no one's gonna book you! No one wants to be known as someone who's dangerous." 
What is most interesting is that the labor conditions of British wrestling are in some ways far worse than the general conditions I have described. While poor pay and infrequent work is prevalent in US independent promotions, a number of wrestlers confirmed to me that absolutely no one makes a living in Britain from wrestling. While there were varying degrees of pay, one could earn as little as $£ 30$ a match. Some experienced workers could earn a few hundred pounds in a weekend, but the infrequency of the work meant that few could survive on wrestling alone and most, if not all, had day jobs: "Some of them hope to like, get to try out and get a spot at WWE, and bigger things, but lots of wrestlers are quite happy to just do this kind of Sunday thing" (J., 4 February 2013). British wrestling is therefore quite different from the other major wrestling nations, such as the US and Mexico, where it is much more likely that one can work to become a "superstar"; or Japan, where wrestlers are contracted employees and earn salaries comparable to full-time jobs. In Britain, wrestling is effectively all grassroots, with the heyday of television promotions having disappeared with the cancellation of ITV's World of Sport in 1985.

The British wrestling scene adds another layer of complexity to the theorizing. As I have argued above, the tacit and embodied knowledge of "work" is a value that lies outside of wage labor. In a purely economic sense, then, lacking the ultimate goal of making a living from wellpaid promotions or television success, wrestlers invest much more in the training and development of their labor than they are likely to earn. In this way, professional wrestling in Britain is "amateur" in the sense of it being a labor of love. Wrestlers in Britain, more than in the United States might be said to engage with the practice for its own sake, making it a form of nonproductive labor. "Work" produces value, it seems, twice. Firstly, it creates a spectacle to be consumed by an audience. But secondly, it creates alternative value for the performers that exists only in the doing. This value is something the audience is not and cannot, ever be in on.

\section{References}

Beekman, Scott. 2006. Ringside: A History of Professional Wrestling in America. Westport, CT: Praeger.

Braverman, Harry. (1974) 1998. Labor and Monopoly Capital: The Degradation of Work in the Twentieth Century. New York: Monthly Review Press.

Browning, Barbara. 1995. Samba: Resistance in Motion. Bloomington: Indiana University Press.

Campbell, John W. 1996. "Professional Wrestling: Why the Bad Guy Wins." The Fournal of American Culture $19,2: 127-32$.

Chow, Broderick D.V. 2013. "Time + Materials: choreographic experiments with labour and finance in The Dangerologists' Work Songs." Choreographic Practices 4, 1:75-94.

Csikszentmihalyi, Mihaly. 1975. Beyond Boredom and Anxiety: Experiencing Flow in Work and Play. San Francisco: Jossey-Bass.

De Garis, Laurence. 1997. "Experiments in Pro Wrestling: Toward a Performative and Sensuous Sport Ethnography.” Sociology of Sport Fournal 16, 1:65-74.

De Garis, Laurence. 2005. "The 'Logic' of Professional Wrestling.” In Steel Chair to the Head: The Pleasure and Pain of Professional Wrestling, ed. Nicholas Sammond, 192-212. Durham, NC: Duke University Press.

Derrida, Jacques, and Anne Dufourmantelle. 2000. Of Hospitality. Trans. Rachel Bowlby. Stanford: Stanford University Press.

Foucault, Michel. (1975) 1991. Discipline and Punish: The Birth of the Prison. Trans. Alan Sheridan. London: Penguin.

Foucault, Michel. 1980. Power/Knowledge: Selected Interviews and Other Writings, 1972-1977, ed. Colin Gordon. New York: Random House.

Frontier Wrestling Alliance. 2011 "Leading actors' union says pro wrestlers can hold Equity cards.” www .fwawrestling.co.uk/news/item/161:leading-actors\%E2\% 80\%99-union-says-pro-wrestlers-can-hold -equity-cards (10 January 2014). 
Gandhi, Leela. 2006. Affective Communities: Anti-Colonial Thought, Fin-de-Siècle Radicalism, and the Politics of Friendship. Durham, NC: Duke University Press.

Garfield, Simon. 1996. The Wrestling: The Hilarious True Story of Britain's Last Great Superheroes. London: Faber and Faber.

Hardt, Michael and Antonio Negri. 2000. Empire. Cambridge, MA: Harvard University Press.

Harvey, David. 2000. Spaces of Hope. Edinburgh: Edinburgh University Press.

Hope, Sophie, and Louise Owen. 2013. "The Passion Industries.” New Left Project. www.newleftproject .org/index.php/site/article_comments/the_passion_industries (10 January 2014).

Jenkins, Henry, III. 2005. “'Never Trust a Snake’: WWF Wrestling as Masculine Melodrama.” In Steel Chair to the Head: The Pleasure and Pain of Professional Wrestling, ed. Nicholas Sammond, 33-66. Durham, NC: Duke University Press.

Kluck, Ted. 2009. Headlocks and Dropkicks: A Butt-Kicking Ride through the World of Professional Wrestling. Santa Barbara, CA: Praeger.

Maguire, Brendan, and John F. Wozniak. 1987. "Racial and Ethnic Stereotypes in Professional Wrestling." Social Science 7ournal 24, 3:261-73.

The March of Progress. 2012. Progress Wrestling. The Garage, Islington, London, UK, 24 June.

Marx, Karl. 1857. Grundrisse. Marxists.org. www.marxists.org/archive/marx/works/1857/grundrisse/ch07 .htm (10 January 2014).

Mazer, Sharon. 1990. “The Doggie Doggie World of Professional Wrestling.” TDR 34, 4 (T128):96-122.

Mazer, Sharon. 1998. Professional Wrestling: Sport and Spectacle. Jackson: University Press of Mississippi.

Mazer, Sharon. 2005. “'Real' Wrestling/'Real' Life.” In Steel Chair to the Head: The Pleasure and Pain of Professional Wrestling, ed. Nicholas Sammond, 67-87. Durham, NC: Duke University Press.

Mujanović, Jasmin. 2011. "The Political Economy of Professional Wrestling.” Politics Respun. politicsrespun .org/2011/05/the-political-economy-of-professional-wrestling-capital-unions-and-spandex/ (10 January 2014).

Priest, Graham, Koji Tanaka, and Zach Weber. 2013. "Paraconsistent Logic.” Stanford Encyclopedia of Philosophy. (12 January 2014).

Rickard, John F. 1999. “'The Spectacle of Excess': The Emergence of Modern Professional Wrestling in the United States and Australia." Zournal of Popular Culture 33, 1:129-37.

Ridout, Nicholas, and Rebecca Schneider. 2012. "Precarity and Performance: An Introduction.” TDR 56, 4 (T216):5-9.

Ronson, Jon. 2007. “The Ring Cycle.” The Guardian. www.theguardian.com/lifeandstyle/2007/dec/08 /weekend.jonronson1 (10 January 2014).

Smith, R. Tyson. 2008. "Passion Work: The Joint Production of Emotional Labor in Professional Wrestling." Social Psychology Ouarterly 71, 2:157-76.

Soulliere, Danielle M., and James A. Blair. 2006. "Muscle-Mania: The Male Body Ideal in Professional Wrestling." International Fournal of Men's Health 5, 3:268-86.

Standing, Guy. 2011. The Precariat: The New Dangerous Class. London: Bloomsbury Academic.

Svendsen, Lars. 2008. Work. The Art of Living. Stocksfield: Acumen.

Wacquant, Loïc. 2004. Body and Soul: Notebooks of An Apprentice Boxer: Oxford: Oxford University Press.

Williams, Raymond. 1977. Marxism and Literature. Oxford: Oxford University Press.

Žižek, Slavoj. 2012. Less Than Nothing: Hegel and the Shadow of Dialectical Materialism. London: Verso. 


\section{This article has been cited by:}

1. 2018. Sharon Mazer Responds to Warden, Chow, and Laine. TDR/The Drama Review 62:2, 216-219. [Citation] [PDF] [PDF Plus]

2. Claire Warden, Broderick Chow, Eero Laine. 2018. Working Loose: A Response to "Donald Trump Shoots the Match" by Sharon Mazer. TDR/The Drama Review 62:2, 201-215. [Citation] [PDF] [PDF Plus]

3. Sharon Mazer. 2018. Donald Trump Shoots the Match. TDR/The Drama Review 62:2, 175-200. [Abstract] [PDF] [PDF Plus] 